Jurnal Riset Agama

Volume 1, Nomor 3 (Desember 2021): 112-131

DOI: $10.15575 /$ jra.v1i3.15112

https://journal.uinsgd.ac.id/index.php/jra

\title{
Revitalisasi Tafsir Ekologi pada Kandungan Surat Al-A'raf [7] Ayat 56- 58 dalam Rencana Penanaman Pohon Trembesi di Lingkungan UIN Walisongo Semarang
}

\author{
Eka Mulyo Yunus1, Andika Pratama², Ahmad Yani' ${ }^{3}$, Muria Khusnun \\ Nisa $^{4}$, Hasyim Muhammad ${ }^{5}$ \\ 1,5Jurusan Ilmu Al-Qur'an dan Tafsir (Tafsir dan Hadits), Fakultas \\ Ushuluddin dan Humaniora, UIN Walisongo Semarang, Indonesia \\ ${ }^{2} J u r u s a n$ Studi Agam-Agama, Fakultas Ushuluddin dan Studi Agama, \\ UIN Sultan Thaha Saifuddin Jambi, Indonesia \\ 3Jurusan Ilmu Al-Qur'an dan Tafsir, Fakultas Adab dan Dakwah, IAIN \\ Pontianak, Indonesia \\ ${ }^{4}$ Jurusan Studi Agama-Agama, Fakultas Ushuluddin, UIN Syarif \\ Hidayatullah Jakarta, Indonesia \\ ekayunus02@gmail.com, andikaandikaa61@gmail.com, \\ ahmadyani.official@gmail.com,muria6@gmail.com, \\ hasyimmuhammad@walisongo.ac.id
}

\begin{abstract}
Climate change caused by emission substances is a real problem. Carbon emissions produced by vehicles, households can erode the climate from time to time. One way to overcome this is by planting tamarind trees. This study aims to analyze the ecological interpretation of Surah Al-A'raf verses 56-58 in the plan to plant trembesi trees at UIN Walisongo Semarang. This study uses a qualitative approach through technical methods according to Miles and Huberman, namely data reduction, data presentation, and drawing conclusions and field observations by direct observation. The results of this study discuss environmental studies, science and religion in one Trembesi tree environment in accordance with Al-A'raf verses 56-58. This study concluded that the Trembesi tree, if calculated by experts, could absorb 28.5 tons of $\mathrm{CO} 2$ gas annually (canopy diameter $15 \mathrm{~m}$ ). So that it becomes an innovation that will be developed at UIN Walisongo Semarang. This research is recommended to commentators, biologists and students as well as government agencies so that the use of Trembesi trees can continue to be developed.
\end{abstract}

Keywords: Climate; Clogical Interpretation; Surah Al-A'raf Verses 56-58; Trembesi Tree; UIN Walisongo Semarang 
Jurnal Riset Agama, Volume 1, Nomor 3 (Desember 2021): 112-131

Eka Mulyo Yunus, Andika, Ahmad Yani, Muria Khusnun Nisa, Hasyim

Muhammad/Revitalisasi Tafsir Ekologi pada Kandungan Surat Al-A'raf [7] Ayat

56-58 dalam Rencana Penanaman Pohon Trembesi di Lingkungan UIN

Walisongo Semarang

\begin{abstract}
Abstrak
Perubahan iklim yang terjadi diakibatkan oleh zat emisi merupakan persoalan yang nyata. Emisi karbon yang dihasilkan oleh kendaraan, rumah tangga dapat mengkikis iklim dari masa ke masa. Salah satu untuk mengatasi hal tersebut adalah dengan melakukan penanaman pohon Trembesi. Penelitian ini bertujuan untuk menganalisis tafsir ekologi dari surat Al-A'raf ayat 56-58 dalam rencana penanaman pohon trembesi di UIN Walisongo Semarang. Penelitian ini menggunakan pendekatan kualitatif melalui metode teknik penelitian berdasarkan Miles dan Huberman, yaitu reduksi data, penyajian data, dan penarikan kesimpulan serta observasi lapangan dengan cara direct observation. Hasil penelitian ini membahas tentang kajian lingkungan, sains dan agama dalam satu lingkungan pohon Trembesi sesuai dengan surat Al-A'raf ayat 56-58. Penelitian ini menyimpulkan pohon Trembesi yang jika dihitung oleh ahli dapat menyerap 28,5 ton gas CO2 setiap tahunnya (diameter tajuk 15m). Sehingga menjadi inovasi yang akan dikembangkan di UIN Walisongo Semarang. Penelitian ini direkomendasikan kepada ahli tafsir, biologi serta mahasiswa dan juga instansi pemerintahan sehingga pemanfaatan pohon Trembesi dapat terus dikembangkan.
\end{abstract}

Kata Kunci: Iklim, Pohon Trembesi; Surat Al-A'raf ayat 56-58; Tafsir Ekologi; UIN Walisongo Semarang

\title{
Pendahuluan
}

Iklim dan lingkungan adalah suatu hal yang selalu berdampingan dengan manusia. Rusaknya lingkungan merupakan sebuah bencana yang mungkin saja akan menandakan moralitas manusia berada di fase paling bawah. Lingkungan hidup, yang selanjutnya disebut alam semesta, dimanifestasikan untuk digunakan oleh manusia dalam melanjutkan evolusinya hingga mencapai tujuan penciptaan (Mustakim, 2017). Allah SWT mempersiapkan alam dan semestanya untuk menjadi bagian fasilitas manusia untuk menjalankan kehidupan sebagai makhluk dan hamba. Sehingga pada saat yang bersamaan manusia berkewajiban untuk menjaga, memelihara, dan melakukan konservasi terhadap berbagai kerusakan yang dialami fasilitas tersebut (Sukarni, 2011). Sejatinya aktivitas manusia dalam kehidupan sehari-hari tidak terlepas dari yang 
Jurnal Riset Agama, Volume 1, Nomor 3 (Desember 2021): 112-131

Eka Mulyo Yunus, Andika, Ahmad Yani, Muria Khusnun Nisa, Hasyim

Muhammad/Revitalisasi Tafsir Ekologi pada Kandungan Surat Al-A'raf [7] Ayat

56-58 dalam Rencana Penanaman Pohon Trembesi di Lingkungan UIN

Walisongo Semarang

namanya pemanfaatan lingkungan hidup, sehingga sudah sepatutnya manusia menjaganya dari kerusakan. Dalam kolaborasi antara sains dan agama, tafsir ekologi menjadi sebuah jalan penengah untuk menjadi rujukan bersama. Melihat riset J.J.G Jansen sebagaimana dikutip oleh Abdul Mustaqim tertulis dalam bukunya Dinamika Sejarah Tafsir AlQur'an, Tafsir Modern Kontemporer dipetakan dalam tiga kategori, yaitu 'ilmi, linguistik-fiologi, dan tafsir praktis. Tafsir praktis merupakan tafsir yang dikaitkan dengan persoalan keseharian manusia, termasuk persoalan keseharian manusia dalam lingkungan (Mustakim, 2017).

Corak tafsir praktis yang sejalan dengan tafsir ekologi akan dirumuskan dalam pembahasan surat al-A'raf (7) ayat 56-58. Tafsir ekologi dalam bahasa Arab dikenal dengan istilah al-tafsir al-bi'i. Ungkapan al-tafsir yang disandingkan dengan al-bi'i secara gramatikal masuk dalam klasifikasi tarkib bayani, bentuk tarkib wasfi, terdiri atas sifah (al-bi'i) dan mausuf (al-tafsir). Pada dasarnya, pengertian tafsir berdasarkan bahasa tidak akan lepas dari kandungan makna al-Idah (menjelaskan), al-Bayan (menerangkan), al-Kasyf (mengungkapkan), alIzhar (menampakkan), dan al-Ibanah (menjelaskan). Jika kita kembali ke latar belakang ekologi, maka ekologi dikembangakan pertama sekali oleh Ernest Haeckel dalam kerangka disiplin ilmu Biologi. Itu menjadi alasan bahwa di awal mulanya ekologi sering disebut sebagai cabang dari biologi pada masa awal-awal perkembangannya yang membahas tentang ekosistem.

Kajian ekologi diselaraskan dengan tafsir praktisi sehingga menjadi tafsir ekologi. Lanjutan dari kajian tersebut menjadi landasan penelitian sebagai bahan rujukan pembahasan surat Al-A'raf (7) ayat 56-58 dalam rencana penanaman pohon Trembesi di lingkungan UIN Walisongo Semarang.

Permasalahan utama di penelitian ini adalah terdapat revitalisasi tafsir ekologi pada kandungan surat al-A'raf [7] ayat 56-58 dalam pengaplikasian penanaman pohon Trembesi di lingkungan UIN Walisongo Semarang. Rumusan masalah penelitian ini ialah bagaimana revitalisasi tafsir ekologi pada kandungan surat al-A'raf [7] ayat 56-58 dalam pengaplikasian penanaman pohon Trembesi di lingkungan UIN Walisongo Semarang. Penelitian ini bertujuan membahas revitalisasi tafsir ekologi pada kandungan surat al-A'raf [7] ayat 56-58 dalam pengaplikasian penanaman pohon Trembesi di lingkungan UIN Walisongo Semarang. Manfaat hasil penelitian ini adalah diambil dari pohon Trembesi yang termasuk pohon yang dapat menghasilkan oksigen yang besar dan dapat mengurangi zat emisi yaitu karbon dioksida, 
Jurnal Riset Agama, Volume 1, Nomor 3 (Desember 2021): 112-131

Eka Mulyo Yunus, Andika, Ahmad Yani, Muria Khusnun Nisa, Hasyim

Muhammad/Revitalisasi Tafsir Ekologi pada Kandungan Surat Al-A'raf [7] Ayat 56-58 dalam Rencana Penanaman Pohon Trembesi di Lingkungan UIN

Walisongo Semarang

penelitian ini sangat lah efisien dengan mengkolaborasikan antara ajaran Islam dan sains.

Diagram 1. Tafsir Ekologi Penanaman Pohon Trembesi
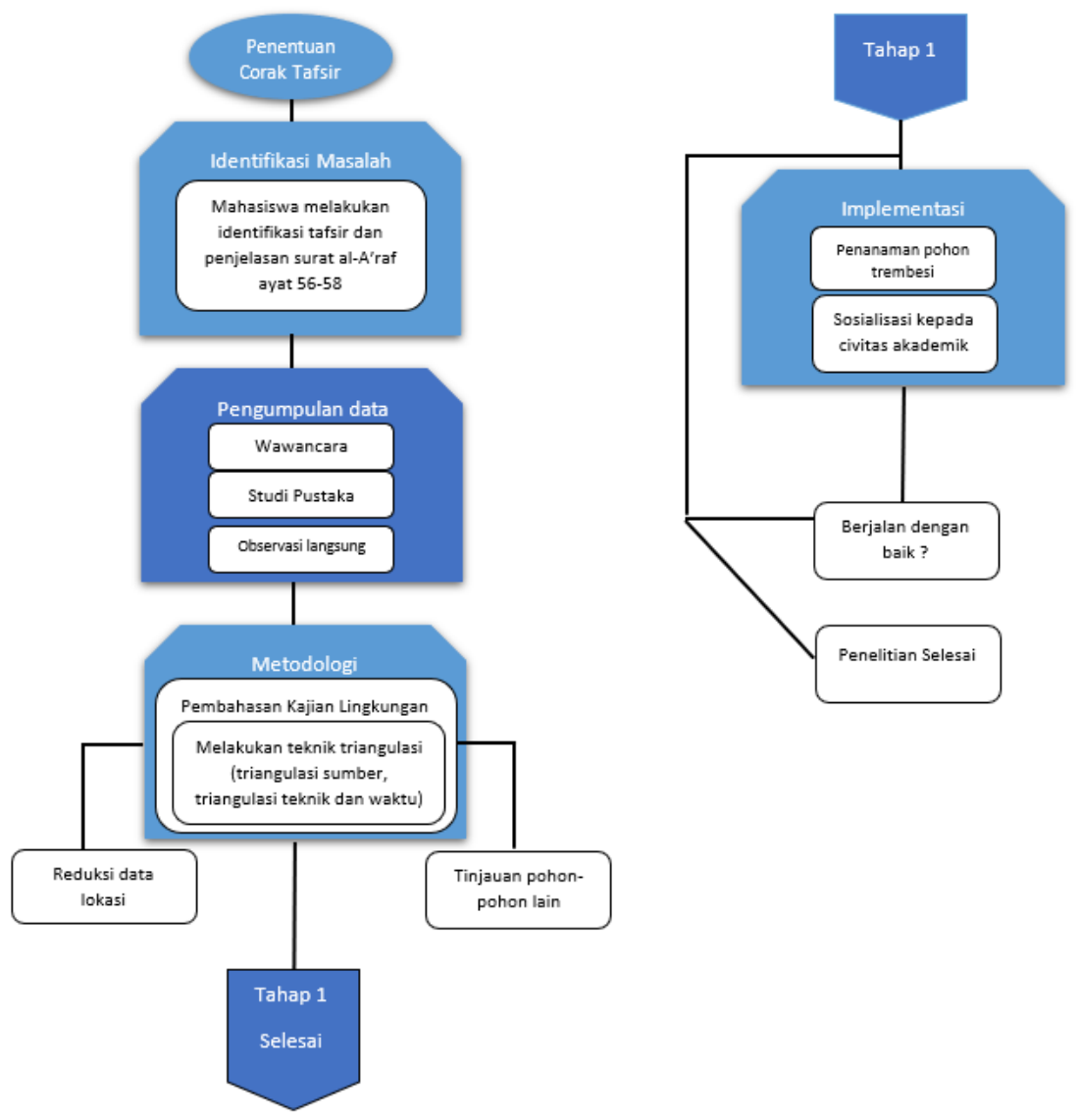

Diagram 1 merupakan kerangka berpikir sebagai alur logis berjalannya penelitian ini. Penentuan corak tafsir ekologi dalam suatu penafsiran yang dilakukan untuk mengkaji objek pembahasan berupa ayat al-Qur'an yang terkait dengan tema ekologi dengan menggunakan analisa keilmuan berbasis ekologi, serta terdapat nuansa kepedulian terhadap lingkungan hidup (Abidin, 2020). Di dalam al-Qur'an banyak sekali ayat yang mengkaji tentang pendidikan lingkungan, salah satunya adalah surah al-A'raf ayat 56-58, penelitian kepustakaan merupakan teknik pengumpulan dan penyajian data yang digunakan dalam penelitian ini adalah teknik dokumenter, yaitu dengan mengedit, menyajikan data, dan menarik kesimpulan. Kemudian analisis menggunakan metode isi yaitu menganalisis isi, pesan, atau komunikasi surah al-A'raf ayat 56-58 (Mustakim, 2017). Pengumpulan data dalam 
Jurnal Riset Agama, Volume 1, Nomor 3 (Desember 2021): 112-131

Eka Mulyo Yunus, Andika, Ahmad Yani, Muria Khusnun Nisa, Hasyim

Muhammad/Revitalisasi Tafsir Ekologi pada Kandungan Surat Al-A'raf [7] Ayat

56-58 dalam Rencana Penanaman Pohon Trembesi di Lingkungan UIN

Walisongo Semarang

penelitian memiliki beberapa hal yang harus dilewati di antaranya wawancara yang dilakukan semi terstruktur, dilanjutkan dengan studi pustaka untuk mendalami penelitian yang akan dilakukan serta observasi lapangan dengan cara direct observation, yaitu peneliti terjun langsung untuk observasi di lapangan tetapi tidak bertindak seperti apa yang dilakukan oleh subjek penelitian. Keabsahan data diuji kredibilitas dengan teknik triangulasi (triangulasi sumber, triangulasi teknik, dan triangulasi waktu). Data penelitian dikaji dengan saksama menurut teknik Miles dan Huberman, yaitu reduksi data, penyajian data, dan penarikan kesimpulan (Denzin, 2009). Penelitian akan dilanjutkan dengan rencana penanaman pohon Trembesi, dimana pohon ini tidak merusak ekosistem lokal terhadap mikroorganisme tanah dan juga tidak ada karona, daun Trembesi serta polongnya mengandung gula yang berguna menjadi humus sehingga menjadi media yang sangat baik untuk mikroorganisme tanah (Dahlan, 2010).

Penelitian terdahulu yang dilakukan kalangan ahli. Antara lain Ahmad Saddad (2017), "Paradigma Tafsir Ekologi," Kontemplasi: Jurnal Ilmu-Ilmu Ushuluddin. Penelitian ini membahas corak-corak baru dalam khazanah tafsir, corak tersebut ialah corak ekologi sehingga tafsir yang berkaitan dengan ekologi dikatakan sebagai tafsir ekologi. Penelitian ini juga menggunakan metode kualitatif dengan metode deskriptif-analitis. Hasil penelitian dan pembahasan menunjukan adanya paradigma tafsir ekologi yang berujung kepada pembahasan ekoteosentris dengan metodologi praktis, tematis, dan menggunakan pendekatan interdisipliner sehingga mewujudkan sebuah pemikiran di mana semua proses dalam kehidupan di muka bumi ini di satu sisi berada dalam hak makhluk ekologi, di sisi lain dipertanggungjawabkan kepada Tuhan. Kesimpulan penelitian ini adalah problem metodologi ekoteosentris, dengan paradigma ekoteosentris manusia di samping memiliki kesadaran penuh untuk tanggung jawab dalam melestarikan lingkungan, juga memiliki kesadaran untuk mempertanggung jawabkan urusan lingkungan tersebut kelak dihadapan Tuhan (Saddad, 2017). Ismayadi Samsoedin, Ari Wibowo (2012) "Analisis Potensi dan Kontribusi Pohon di Perkotaan dalam Menyerap Gas Rumah Kaca: Studi Kasus Taman Kota Monumen Nasional, Jakarta," E-Journal: Jurnal Penelitian Sosial dan Ekonomi Kehutanan. Artikel ini membahas tentang upaya mitigasi perubahan iklim, yaitu dengan cara penurunan emisi gas rumah kaca dengan cara penanaman pohon di sekitar kota, salah satunya adalah penanaman pohon Trembesi. Penelitian ini menggunakan metode kualitatif dengan metode penelitian dan pengembangan dengan cara mengukur diameter, tinggi dan berat jenis pohon. Sebanyak 64 jenis pohon yang berumur rata- 
Jurnal Riset Agama, Volume 1, Nomor 3 (Desember 2021): 112-131

Eka Mulyo Yunus, Andika, Ahmad Yani, Muria Khusnun Nisa, Hasyim

Muhammad/Revitalisasi Tafsir Ekologi pada Kandungan Surat Al-A'raf [7] Ayat

56-58 dalam Rencana Penanaman Pohon Trembesi di Lingkungan UIN

Walisongo Semarang

rata lima tahun diukur dan dianalisis untuk dihitung kemampuannya dalam menyerap karbon. Hasil perhitungan menunjukkan kandungan rata-rata karbon per pohon adalah 0,33 ton sehingga rata-rata potensi karbon per hektar adalah 19,8 ton atau 39,6 ton biomas per hektar. Hasil dari penelitian ini adalah pengembangan model taman kota yang akan dibangun sehingga dalam role model tersebut dapat menginisiasi pengurangan zat emisi. Mengambil kesimpulan dari penelitian ini hasil pengamatan di Taman Kota Monas menunjukkan bahwa taman kota ini dipelihara secara rutin (penyiangan sekitar batang bawah) per individu pohon. Hal ini dilakukan dengan tujuan agar setiap individu pohon secara estetika memiliki nilai baik, tidak terjadi kompetisi hara dan dapat diamati secara mendetail kondisi kesehatan dan pertumbuhannya sehingga dari hasil perhitungan potensi karbon, kandungan rata-rata per pohon adalah 0,33 ton sehingga rata-rata potensi karbon per hektar adalah 19,8 ton karbon per hektar atau 39,6 ton biomassa/hektar. Potensi ini masih akan meningkat karena pada umumnya jenis pohon yang ada di Taman Kota Monas masih dalam fase pertumbuhan (rata-rata umur 5 tahun) (Samsoedin \& Wibowo, 2012). Mustakim (2017), "Pendidikan Lingkungan Hidup dan Implementasinya dalam Pendidikan Islam (Analisis Surat al-A'raf Ayat 56-58 Tafsir al-Misbah Karya M. Quraish Shihab)," JIE: Journal of Islamic Education. Penelitian ini dilakukan karena munculnya berbagai kerusakan lingkungan akibat tindakan manusia dalam mengelolanya. Jika kita melihat Al-Qur'an kembali, banyak sekali ayat yang menjelaskan tentang pendidikan lingkungan, salah satunya adalah surah al-A'raf ayat 56-58. Pendekatan dalam penelitian ini merupakan sebuah pendekatan kualitatif. Jenis penelitian ini menggunakan acuan penelitian kepustakaan dengan teknik pengumpulan data yang digunakan dalam penelitian ini adalah teknik dokumenter, yaitu dengan mengedit, menyajikan data, dan menarik kesimpulan. Kemudian analisis menggunakan metode isi yaitu menganalisis isi, pesan, atau komunikasi surah al-A'raf ayat 56-58 dalam tafsir al-Misbah karya M. Quraish Shihab tentang nilai pendidikan lingkungan hidup dan implementasinya dalam pendidikan Islam. Kesimpulan pada penelitian ini lingkungan hidup merupakan fasilitas yang diberikan kepada manusia, Allah Swt memberikan fasilitas berupa lingkungan hidup kepada manusia agar mereka dapat melaksanakan perintah-Nya dan menjauhi larangan-Nya dengan baik. Larangan merusak lingkungan hidup, karena merusak lingkungan hidup bukan hanya merugikan diri sendiri, tetapi juga mengganggu keseimbangan seluruh kehidupan di dunia (Mustakim, 2017). 
Jurnal Riset Agama, Volume 1, Nomor 3 (Desember 2021): 112-131

Eka Mulyo Yunus, Andika, Ahmad Yani, Muria Khusnun Nisa, Hasyim

Muhammad/Revitalisasi Tafsir Ekologi pada Kandungan Surat Al-A'raf [7] Ayat

56-58 dalam Rencana Penanaman Pohon Trembesi di Lingkungan UIN

Walisongo Semarang

Penelitian terdahulu telah menyinggung problematika dan paradigma tafsir ekologi dengan pembahasan ekoteosentris (Saddad, 2017). Dalam pembahasan lebih lanjut konservasi pohon Trembesi dilakukan dengan cara pembahasan secara lapangan dilihat dari strategisasi tempat penanaman dan tata letak taman (Samsoedin \& Wibowo, 2012). Perbedaan secara teoritis dengan berlandaskan tafsir AlMisbah karya M. Quraish Shihab yang dijadikan rujukan untuk pembahasan surat al-A'raf ayat 56-58.

Sebagai landasan teoritis peneltian ini maka dibutuhkan suatu tinjauan pustaka. Tafsir ekologi merupakan salah satu terminologi baru dalam ranah kajian tafsir al-Qur'an. Tafsir ekologi dalam bahasa Arab dikenal dengan istilah al-tafsir al-bi'i. Secara terminologi tafsir ekologi merupakan suatu penafsiran yang dilakukan dengan objek penafsiran berupa ayat- ayat al-Qur'an yang terkait dengan tema ekologi, dengan menggunakan analisa keilmuan berbasis ekologi, serta terdapat nuansa keberpihakan terhadap permasalahan lingkungan hidup (Abidin, 2020). Studi ini meliputi kajian al-Qur'an, lingkungan, sains-teknologi, dan timbal balik kepada manusia (Abidin, 2020). Permasalahan lingkungan merupakan kondisi-kondisi dalam lingkungan yang menghalangi pemenuhan kebutuhan. Dalam pembahasannya tafsir ekologi terkait dengan lingkungan dalam surat al-A'raf ayat 56-58, ayat ini melarang berbuat kerusakan di bumi, yang mana berbuat kerusakan merupakan salah bentuk pelampauan batas Secara epistemologis, analisis penelitian ini menggunakan metode isi yaitu menganalisis isi, pesan, atau komunikasi surah al-A'raf ayat 56-58 (Mustakim, 2017). Sehingga pohon trembesi dapat menjadi objek dalam tafsir ekologi yang berdaya lingkungan. Menurut Dahlan, pohon trembesi memiliki daya serap gas karbondioksida yang sangat tinggi. Satu batang atau dahan pohon Trembesi mampu menyerap 28,5 ton gas CO2 setiap tahunnya (diameter tajuk $15 \mathrm{~m}$ ). Dahlan juga meriset setidaknya terdapat 43 pohon trembesi yang sering dimanfaatkan sebagai tanaman penghijauan adalah pohon trembesi (Dahlan, 2010). Hasilnya, pohon trembesi terbukti paling banyak menyerap karbondioksida dan memiliki kemampuan menyerap air tanah yang kuat. Dalam kurun waktu setahun, tanaman tersebut dapat menyerap 28,488,39 kilogram karbondioksida.

\section{Metodologi Penelitan}

Penelitian ini memiliki lima macam bagian, yaitu dengan pendekatan dan metode penelitian, jenis dan sumber data, teknik pengumpulan data, teknik analisis data dan tempat serta waktu penelitian. Pendekatan ini menggunakan studi kualitatif melalui observer 
Jurnal Riset Agama, Volume 1, Nomor 3 (Desember 2021): 112-131

Eka Mulyo Yunus, Andika, Ahmad Yani, Muria Khusnun Nisa, Hasyim

Muhammad/Revitalisasi Tafsir Ekologi pada Kandungan Surat Al-A'raf [7] Ayat

56-58 dalam Rencana Penanaman Pohon Trembesi di Lingkungan UIN

Walisongo Semarang

lapangan (Darmalaksana, 2020). Untuk mendalami penelitian yang akan dilakukan serta observasi lapangan dengan cara direct observation, yaitu peneliti terjun langsung untuk observasi di lapangan tetapi tidak bertindak seperti apa yang dilakukan oleh subyek penelitian. Teknis data pada penelitian ini merupakan data kualitatif dan sumber data meliputi primer dan sekunder. Sumber data primer diambil dari lapangan sedangkan sumber data sekunder dinukil dari sumber kepustakaan meliputi artikel jurnal, buku, dokumen hasil penelitian, dan lain-lain. Kemudian analisis menggunakan metode isi yaitu menganalisis isi, pesan, atau komunikasi surah al-A'raf ayat 56-58 (Mustakim, 2017). Teknik analisis data dilakukan melalui inventarisasi, klasifikasi, dan interpretasi. Secara khusus, interpretasi dalam penelitian ini digunakan analisis isi (Hsieh, 2005). Penelitian akan dilaksanakan di UIN Walisongo Semarang.

\section{Hasil dan Pembahasan Penelitian}

\section{Tafsir Ekologi dan Kaitan Terhadap Surat Al-A'raf ayat 56-58}

Tafsir ekologi dalam bahasa Arab dikenal dengan istilah al-tafsir albi'i. Pemaparan ekologi memiliki penjelasan yang luas (Junaidi, 2014). Haeckle memiliki pendapat sehingga menjelaskan pengertian yang cukup komprehensif, diambil oleh S.J. Mcnaughton \& Larry. L, dalam buku Ekologi Umum, yaitu ekologi sebagai suatu keseluruhan pengetahuan yang berhubungan dengan keterkaitan total antara organisme dengan lingkungannya yang bersifat organik maupun anorganik (Sakti Garwan, 2019). Senada dengan itu, Mujiyono juga memperdalam penjelasan tentang ekologi sebagai cabang ilmu yang meneliti tentang beraneka instrumen kehidupan, yaitu: 1) Asal muasal organisme atau makhluk hidup di teritorinya; 2) Perjalanan dan pelaksanaan fungsi makhluk hidup dan teritorinya; dan 3) Ikatan di antara komponen secara menyeluruh (Abdillah, 2001).

Secara terminologi tafsir ekologi merupakan suatu penafsiran yang dilakukan dengan objek penafsiran berupa ayat-ayat al-Qur'an yang terkait dengan tema ekologi, dengan menggunakan analisa keilmuan berbasis ekologi, serta terdapat nuansa keberpihakan terhadap permasalahan lingkungan hidup (Abidin, 2020). Studi ini meliputi kajian al-Qur'an, lingkungan, sains-teknologi, dan timbal balik kepada manusia (Abidin, 2020). Al-Qur'an sendiri memiliki banyak sekali pembahasan di dalamnya, termasuk pembahasan tentang lingkungan.

Pembahasan di dalam lingkungan sendiri sudah dibahas di dalam surat Al-A'raf ayat 56-58 yang berbunyi: 
Jurnal Riset Agama, Volume 1, Nomor 3 (Desember 2021): 112-131

Eka Mulyo Yunus, Andika, Ahmad Yani, Muria Khusnun Nisa, Hasyim

Muhammad/Revitalisasi Tafsir Ekologi pada Kandungan Surat Al-A'raf [7] Ayat 56-58 dalam Rencana Penanaman Pohon Trembesi di Lingkungan UIN Walisongo Semarang

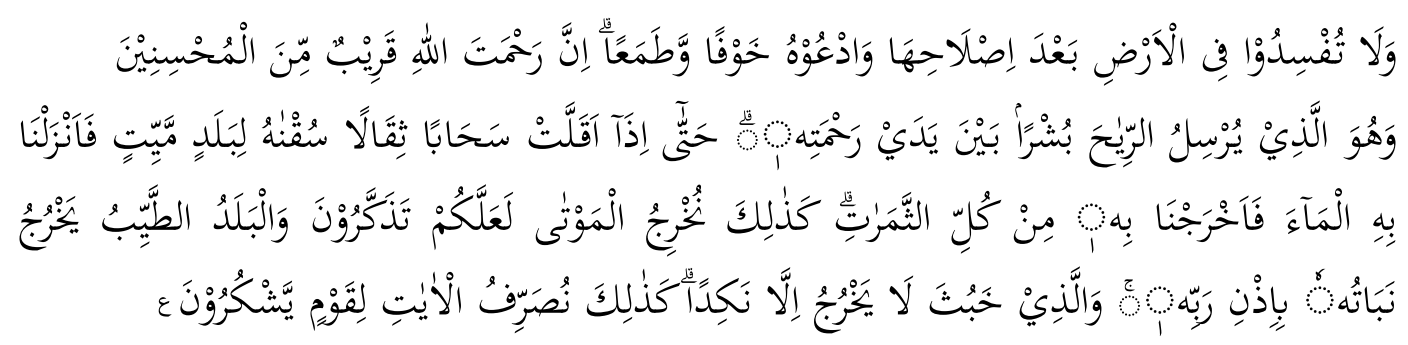

Artinya: "Dan janganlah kamu membuat kerusakan di muka bumi, sesudah (Allah) memperbaikinya dan berdo'alah kepadaNya dengan rasa takut (tidak akan diterima) dan harapan (akan dikabulkan). Sesungguhnya rahmat Allah amat dekat kepada orang-orang yang berbuat baik. Dan Dialah yang meniupkan angin sebagai pembawa berita gembira sebelum kedatangan rahmat-Nya (hujan); hingga apabila angin itu telah membawa awan mendung, Kami halau ke suatu daerah yang tandus, lalu Kami turunkan hujan di daerah itu, Maka Kami keluarkan dengan sebab hujan itu pelbagai macam buahbuahan. Seperti itulah Kami membangkitkan orang-orang yang telah mati, Mudah-mudahan kamu mengambil pelajaran.Dan tanah yang baik, tanaman-tanamannya tumbuh subur dengan seizin Allah; dan tanah yang tidak subur, tanaman-tanamannya hanya tumbuh merana. Demikianlah Kami mengulangi tanda-tanda kebesaran (Kami) bagi orang-orang yang bersyukur."

Isi kandungan ayat 56-58. Pertama, ayat 56. Ayat ini memiliki larangan untuk melakukan kerusakan di bumi, yang mana berbuat kerusakan merupakan salah satu bentuk hal yang melampaui batas. Alam semesta diciptakan Allah SWT dalam keadaan yang harmonis, serasi, serta turut memenuhi kebutuhan makhluk. Allah Swt telah menciptakan alam dan semestanya dalam keadaan baik, serta memerintahkan hambahambanya untuk menjaga dan memperbaikinya.

Salah satu cara pelestarian yang dilakukan oleh Allah Swt adalah dengan mengutus para Nabi dan Rasul Allah untuk meluruskan dan membenahi kehidupan di masyarakat. Maka, apabila merusak setelah diperbaiki jauh lebih buruk daripada merusak sebelum diperbaiki. Karena ayat tersebut secara tegas melarangan hal tersebut, walaupun menambah kerusakan atau merusak sesuatu yang baik juga dilarang (Mustakim, 2017).

Larangan untuk melakukan kerusakan ini mencakup semua bidang, seperti merusak jasmani, norma, ibadah orang lain, kehidupan dan sumber-sumber penghidupan (pertanian, perdagangan, dan lain-lain), 
Jurnal Riset Agama, Volume 1, Nomor 3 (Desember 2021): 112-131

Eka Mulyo Yunus, Andika, Ahmad Yani, Muria Khusnun Nisa, Hasyim

Muhammad/Revitalisasi Tafsir Ekologi pada Kandungan Surat Al-A'raf [7] Ayat

56-58 dalam Rencana Penanaman Pohon Trembesi di Lingkungan UIN

Walisongo Semarang

merusak lingkungan hidup, dan sebagainya. Allah Swt menciptakan bumi dan isinya dengan segala kelengkapannya ditujukan kepada manusia agar dimanfaatkan dengan semestinya untuk kesejahteraan mereka.

Alasan diciptakannya manusia dengan kesempurnaan alam semesta semata-mata hanya untuk mempertuhankan Allah Swt. Agar manusia mencapai suatu kedudukan yang tinggi, maka manusia dituntut harus bertanggung jawab terhadap perbuatannya (Hamdani, 2007).

Pada akhir ayat ini disuratkan "Sesungguhnya rahmat Allah amat dekat kepada orang-orang yang berbuat baik." Hal ini dapat dikaitkan dengan firman Allah SWT dalam surat Ar-Rahman ayat 60:

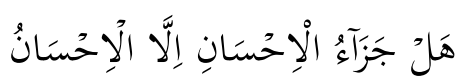

Artinya: “Tidak ada balasan kebaikan kecuali kebaikan (pula).”

Diambil dalam penjelasan tafsir Al-Maraghi dengan penjelasan "maka barang siapa yang melaksanakan ibadah dengan baik, maka akan memperoleh balasan yang baik pula." Dalam hal ini, Allah SWT sebagai Tuhan semesta alam menyerukan untuk berbuat baik dalam segala hal dan mengharamkan segala berbuat jahat dalam segala hal.

Kedua, ayat 57. Ayat 57 menjelaskan tentang salah satu nikmat Allah Swt yang diberikan kepada manusia sebagai fasilitas pendukung kehidupan di dunia. Allah Swt menggerakkan angin yang berisikan awan tebal ke negeri tandus yang telah hancur tanamannya karena tidak adanya air (sumurnya kering tanpa air dan tidak ada hujan) sehingga penduduknya menderita haus dan kelaparan. Lalu kemudian turunlah hujan yang lebat (dari awan tersebut) sehingga negeri yang tandus tersebut kembali menjadi negeri yang subur (sumur-sumurnya terisi dengan air dan tanaman-tanaman yang berlimpah).

Sebelum turunnya hujan, Allah Swt akan membuat angin yang sedikit demi sedikit menggerakkan partikel-partikel awan yang mengandung air, kemudian awan tersebut saling menjadi berkumpul dan berhimpit lalu menjadi satu gumpalan awan, lalu turunlah hujan yang menyuburkan. Ketika partikel-partikel awan tersebut tertiup angin, seakan-akan awan tersebut seperti masih ringan, kemudian setelah menyatu awan tersebut menjadi gumpalan sehingga menjadi berat sehingga gerakannya menjadi lambat. Hal tersebut menunjukkan kuasa Allah SWT akan menurunkan hujan (Mustakim, 2017).

Hujan yang menyebabkan tanah yang tandus menjadi hidup kembali tersebut menurut analisa para pakar ilmu pengetahuan di 
Jurnal Riset Agama, Volume 1, Nomor 3 (Desember 2021): 112-131

Eka Mulyo Yunus, Andika, Ahmad Yani, Muria Khusnun Nisa, Hasyim

Muhammad/Revitalisasi Tafsir Ekologi pada Kandungan Surat Al-A'raf [7] Ayat

56-58 dalam Rencana Penanaman Pohon Trembesi di Lingkungan UIN

Walisongo Semarang

samping berupa butiran-butiran air, ternyata juga mengandung material yang berfungsi sebagai pupuk tanaman. Saat air laut menguap dan mencapai awan, air tersebut mengandung zat-zat yang dapat menghidupkan kembali daratan yang tandus.

Ketiga, ayat 58. Menurut ayat ini, tanah di dataran bumi ini ada yang tandus dan subur, dan ada pula yang tidak baik. Tanah yang sehat dan subur apabila disirami air hujan sedikit saja, akan dapat menumbuhkan berbagai jenis tanaman-tanaman yang beranekaragam. Berbanding terbalik dengan tanah yang tandus walaupun disirami hujan yang lebat, namun tumbuhan-tumbuhannya layu dan tidak menghasilkan apa-apa. Tanaman-tanaman tumbuh subur di tanah subur tersebut karena mendapat nikmat khusus dari Allah Swt dan diizinkan untuk menjadi yang tanaman terbaik. Berbeda dengan tanaman yang tidak subur di tanah tandus yang mana tidak mendapatkan anugerah dan izin dari Allah Swt sehingga tidak bisa menjadi yang tanaman terbaik.

Hal tersebut kemudian dijadikan perumpamaan bagi sifat manusia, yaitu ada yang memiliki sifat baik dan sifat buruk. Manusia yang baik mendapati perlakuan yang lebih dan nikmat dari Allah SWT, yaitu manusia yang hatinya suci, selalu berusaha selalu mendekatkan diri kepada Allah SWT melalui perintah agama dan sunnah-sunnahnya. Hal ini berkesimpulan bahwa mereka telah mendapatkan ridho dari Allah SWT untuk mengedarai segala anugerah dari Allah SWT dengan baik (Mustakim, 2017). Namun sebaliknya, orang yang memiliki sifat buruk di dalam dirinya tidak mendapat anugerah dari Allah SWT, tetapi mereka mendapatkan bencana dan siksa dari-Nya.

\section{Korelasi Kajian Tafsir Ekologi dengan Rencana Penanaman Pohon Trembesi}

Penelitian terkait dengan tema ekologi juga pernah dibahas oleh Mardiana dengan judul "Kajian Tafsir Tematik Tentang Pelestarian Lingkungan Hidup." Melalui penelitian ini Mardiana mengikat kata-kata kunci yang terkait pembahasan tentang lingkungan dalam Al-Qur`an, antara lain: Fauna (al-'Anam, al-Dabbah), Flora (al-Harth, Nabat), Tanah (al'Ard), Air (al-Ma'), dan Udara (al-Rih). Ditambah dengan uraian tentang pentingnya pelestarian lingkungan dalam perspektif Al-Quran demi kelangsungan kehidupan. Dilanjutkan dengan penawaran ide pelestarian lingkungan hidup, melalui: 1) pemeliharaan dan pelestarian terhadap hewan; 2) melakukan penanaman pohon yang berskala serta penghijauan lahan tandus; 3) air dan udara dimanfaatkan secara baik untuk kepentingan keberlangsungan ekosistem.

Letak perbedaan penelitian Mardiana dengan penelitian penulis terdapat pada aspek ekologi sebagai objek kajian. Tema ekologi dalam 
Jurnal Riset Agama, Volume 1, Nomor 3 (Desember 2021): 112-131

Eka Mulyo Yunus, Andika, Ahmad Yani, Muria Khusnun Nisa, Hasyim

Muhammad/Revitalisasi Tafsir Ekologi pada Kandungan Surat Al-A'raf [7] Ayat

56-58 dalam Rencana Penanaman Pohon Trembesi di Lingkungan UIN

Walisongo Semarang

artikel ini, penulis awali dengan penjelasan terkait historisitas dan definisi tafsir ekologi, yang berperan penting sebagai instrumen penafsiran terhadap ayat-ayat dengan muatan ekologi yakni dalam surat Al-A'raf ayat 56-58. Kemudian, dari hasil penafsiran dengan pendekatan ekologis tersebut, penulis narasikan dalam dua konsep pelestarian lingkungan dalam al-Qu'ran berdasarkan kajian ilmuwan biologi terhadap pohon Trembesi.

Penelitian ini akan membawa korelasi surat Al-A'raf ayat 56-58 dengan rencana penanaman pohon Trembesi di lingkungan UIN Walisongo Semarang. Sebagai landasan dari penelitian ini ialah dengan melihat perubahan iklim global yang saat ini menjadi isu penting yang terus bergulir dalam beberapa tahun ini dan beberapa tahun yang akan datang. Perubahan iklim global telah dan akan terus terjadi sealur dengan peningkatan aktivitas manusia yang mengkonsumsi energi yang tidak dapat diperbaharui, khususnya energi dari bahan bakar fosil. Ditambah dengan, aktivitas degradasi dan deforestasi akan terus meningkatkan zat emisi karbon yang ada di atmosfer. Emisi karbon di Indonesia saat ini didominasi oleh emisi dari bahan bakar fosil dan aktivitas deforestasi. Sebagai negara kepulauan, Indonesia sangat rentan terhadap dampak dari perubahan iklim (Susandi, 2009).

Meninjau tekad pemerintah pada tahun 2020 yang berupaya untuk mengurangi emisi karbon sebanyak $26 \%$ belum tercapai secara maksimal. Bahkan yang menjadi perbincangan saat ini adalah rencana Indonesia menjadi negara maju dengan menjaring dana carbon trade dari negara maju melalui carbon trade malah akan membuat Indonesia akan mengalami kemunduran ekonomi. Indonesia yang saat ini menjadi salah satu negara yang memiliki populasi penduduk yang sangat besar dan berbagai macam tingkat kebutuhan sangat memerlukan inovasi pengembangan dari berbagai sektor. Maka dari itu, sangat tidak memungkinkan pemerintah menurunkan penggunaan zat emisi yang disebabkan oleh kendaraan, transportasi umum, pabrik-pabrik, serta industri pertanian, dikarenakan hal tersebut menjadi faktor lintas kehidupan di dalam masyarakat (Putra Haska, Dwi Lestari, \& Fitria, 2011).

Meninjau hal ini pula, salah satu sumber daya yang patut untuk dipertimbangakan dan potensial untuk digunakan dalam penyerapan karbon yang menyebabkan emisi adalah sektor kehutanan. Menurut (Cifor, 2009), emisi yang disebabkan oleh deforestasi dan degradasi hutan mencapai sekitar 20\% dari keseluruhan emisi gas rumah kaca (GRK) per tahun. Jumlah ini lebih besar dari emisi yang dikeluarkan oleh sektor transportasi secara menyeluruh. Penurunan emisi dapat dilakukan 
Jurnal Riset Agama, Volume 1, Nomor 3 (Desember 2021): 112-131

Eka Mulyo Yunus, Andika, Ahmad Yani, Muria Khusnun Nisa, Hasyim

Muhammad/Revitalisasi Tafsir Ekologi pada Kandungan Surat Al-A'raf [7] Ayat

56-58 dalam Rencana Penanaman Pohon Trembesi di Lingkungan UIN

Walisongo Semarang

dengan pemeliharaan dan penanaman pohon yang memiliki penyerapan yang tinggi terhadap emisi karbon.

Trembesi (Samanea saman) yang kita kenal saat ini memang bukan spesies pohon asli lndonesia. Namun tumbuhan berkayu yang kekar, kuat, serta rindang serta memiliki bentuk kanopi yang memayung ini tidak asing lagi bagi masyarakat lndonesia di desa maupun kota sebagai peneduh jalan. Trembesi yang merupakan tumbuhan pohon besar dengan ketinggian hingga 20 meter dan ranting dan dedaunan yang memiliki cakupan luas. Pohon Trembesi (Ki Hujan) mempunyai jaringan akar yang sangat kuat serta luas. Pohon Trembesi (Samanea saman) disebut juga sebagai pohon hujan atau Ki Hujan dikarenakan air yang sering menetes dari tajuknya karena kemampuannya menyerap air tanah yang kuat. Di beberapa daerah di Indonesia pohon ini sering memiliki beberapa sebutan di antaranya, kayu ambon (Melayu), trembesi, munggur, punggur, meh (Jawa), ki hujan (Sunda). Trembesi tahan akan serangan jamur dan rayap. Tidak hanya itu, polong buahnya dapat dimanfaatkan sebagai pakan oleh hewan ternak yang biasa terdapat di area padang penggembalaan, seperti: kuda, kambing dan domba. Serangga seperti semut dan lebah juga sering terlihat menghisap buahnya yang memang rasanya manis. Trembesi merupakan salah satu jenis tanaman cepat tumbuh (fast growing species) yang tumbuh sangat baik pada tanah dengan drainase yang baik. Menurut Dahlan, pohon trembesi memiliki daya serap gas karbondioksida yang sangat tinggi (Dahlan, 2010). Satu batang pohon Trembesi mampu menyerap 28,5 ton gas CO2 setiap tahunnya (diameter tajuk $15 \mathrm{~m}$ ). Dahlan juga meriset 43 pohon trembesi yang sering dimanfaatkan sebagai tanaman penghijauan adalah pohon Trembesi (Dahlan, 2010). Hasilnya, pohon trembesi terbukti paling banyak menyerap karbondioksida dan memiliki kemampuan menyerap air tanah yang kuat. Dalam setahun, tanaman tersebut dapat menyerap 28,488,39 kilogram karbondioksida.

Pohon Trembesi mampu mencapai ketinggian 20-25 meter dengan diameter tajuk 15-20 meter. Pohon ini tidak akan merusak ekosistem lokal terhadap mikroorganisme tanah dan juga tidak ada karona daun Trembesi serta buah polongnya yang mengandung gula akan lapuk sehingga akan menjadi humus yang merupakan media yang sangat baik untuk mikroorganisme tanah (Dahlan, 2010). 
Jurnal Riset Agama, Volume 1, Nomor 3 (Desember 2021): 112-131

Eka Mulyo Yunus, Andika, Ahmad Yani, Muria Khusnun Nisa, Hasyim

Muhammad/Revitalisasi Tafsir Ekologi pada Kandungan Surat Al-A'raf [7] Ayat 56-58 dalam Rencana Penanaman Pohon Trembesi di Lingkungan UIN Walisongo Semarang

Gambar 2. Foto Pohon Trembesi atau Ki Hujan

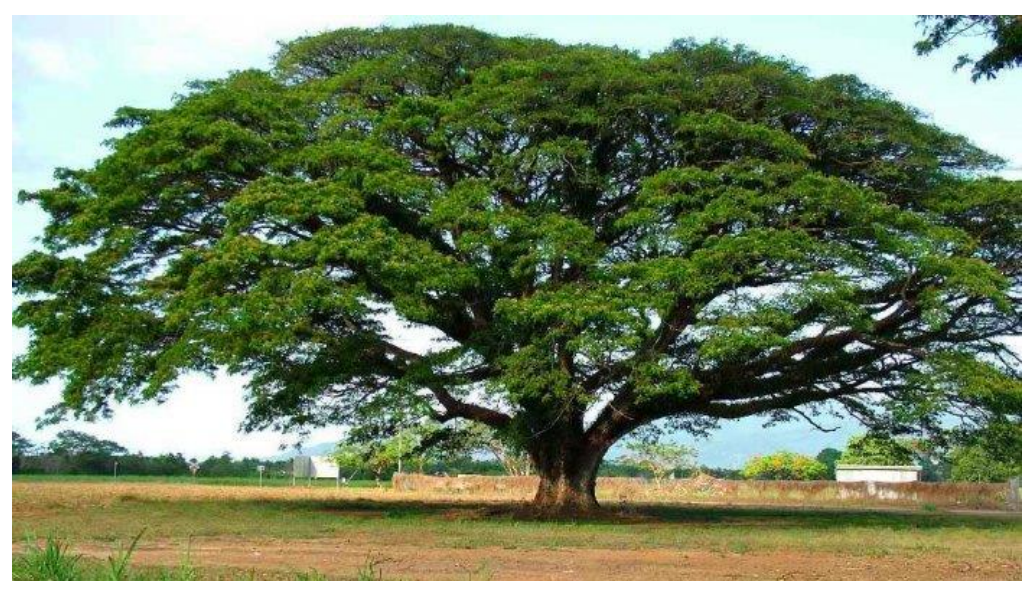

Jika kita melihat data pada tahun 2020, maka pertumbuhan emisi yang dihasilkan Indonesia tumbuh sampai 1,9\% pertahun dan bisa mencapai 2,5 Gt CO2e pada tahun tersebut. Dapat kita kalkulasikan dengan penurunan emisi yang dapat dihasilkan oleh pohon Trembesi maka:

Jumlah pohon $=$ emisi karbon pada tahun 2020

penyerapan karbon per pohon $(\mathrm{Kg})$

$$
\begin{aligned}
& =\frac{2.500 .000 .000 . t o n ~ C O 2 e}{28.488 .39 \mathrm{Kg} \mathrm{CO} 2} \\
& =\frac{2.500 .000 .000 .000 \mathrm{Kg} \mathrm{CO} 2 e}{28.488 .39 \mathrm{Kg} \mathrm{CO} 2} \\
& =87.755 .047 \text { pohon }
\end{aligned}
$$

Melihat opini lebar akar trembesi 15 m (ke kiri dan ke kanan) kita dapat memperkirakan jarak tanam dari pohon tersebut. Sehingga luasan area yang dibutuhkan untuk total penanaman juga dapat kita prediksi.

$$
1 \text { Ha areal }=\underline{10.000 m 2}=44 \text { pohon }
$$

$$
(15 \times 15) m 2
$$

Jika kita perkirakan bersama pohon trembesi dapat menurunkan/mengurangi emisi karbon, jika melakukan penanaman 87.755.047 pohon di Indonesia, dengan perkiraan lahan yang digunakan \pm 2 juta Ha. Sehingga pemerintah Indonesia dapat mengurangi zat emisi yang ada di Indonesia tanpa harus memberhentikan sektor-sektor vital yang lain. 
Jurnal Riset Agama, Volume 1, Nomor 3 (Desember 2021): 112-131

Eka Mulyo Yunus, Andika, Ahmad Yani, Muria Khusnun Nisa, Hasyim

Muhammad/Revitalisasi Tafsir Ekologi pada Kandungan Surat Al-A'raf [7] Ayat

56-58 dalam Rencana Penanaman Pohon Trembesi di Lingkungan UIN

Walisongo Semarang

\section{Kondisi Iklim Global Saat Ini}

Diambil dari penelitian Dewan Nasional Perubahan Iklim, emisi yang dihasilkan Indonesia pada tahun 2005 diperkirakan sebesar 2,1 Gt $\mathrm{CO} 2 \mathrm{e}$, sehingga menyebabkan Indonesia termasuk di antara negara pengekspor emisi terbesar di dunia (satu gigaton atau sebanding dengan 1 miliar ton). 85\% dari zat emisi ini dihasilkan dari cara manusia menggunakan lahan, dalam tata guna lahan, dan pertanian, ditambah dengan pengalihgunaan sektor di dalam wilayah hutan dan dataran gambut. Emisi yang dihasilkan saat ini, 41\% berasal dari pengolahan oksidasi lahan gambut, secara sedikit demi sedikit melalui pembukaan parit, atau secara cepat dari kebakaran lahan gambut. Deforestasi hutan dan lahan gambut menambah setidaknya 0,2 Gt CO2e. 30\% dari total emisi Indonesia berasal dari tindakan-tindakan di hutan dengan lahan non-gambut, dimulai dari deforestasi, pengikisan hutan atau kebakaran hutan. Tingkat deforestasi (selain lahan gambut) mencapai hampir 0,8 juta hektar per tahun dan degradasi hutan kurang lebih seluas 1 juta hektar per tahun. Tingkat deforestasi masa ini di kawasan lahan gambut mencapai 0.3 juta hektar per tahun dan hutan terdegradasi setidaknya sebesar 0,2 juta hektar per tahun. Banyak sumber penyalur emisi yang saat ini sangat tidak produktif secara ekonomi.

Kebakaran lahan tanah gambut merugikan Indonesia hingga 4 miliar dolar AS per tahun dikarenakan kerugian yang bersifat material, logistik yang tertunda dan masalah kesehatan dari penduduk lokal. Emisi dari bagian transportasi dan pembangkit listrik memberikan kontribusi yang relatif kecil, namun persentase berkembang dengan cepat dan kemungkinan mencapai 0,8 Gt CO2e dan 0,4 Gt CO2e pada tahun 2030.

Tabel 1. Penggunaan Rumah Tangga serta Zat Emisi yang Dihasilkan

\begin{tabular}{ccc}
\hline Aktivitas & $\begin{array}{c}\text { Emisi yang } \\
\text { Dihasilkan }\end{array}$ & Sumber \\
\hline $\begin{array}{c}\text { Pemakaian listrik di } \\
\text { rumah kecil dengan } \\
\text { daya 10 kWh per } \\
\text { bulan }\end{array}$ & 4 Kilogram CO2 & safeclimate.net \\
\hline $\begin{array}{c}\text { Pemakaian listrik di } \\
\text { rumah besar dengan } \\
\text { berdaya 10 kWh per } \\
\text { bulan }\end{array}$ & 10 Kilogram CO2 & carbonfootprint.com \\
\hline $\begin{array}{c}\text { Mengendarai mobil } \\
\text { dengan efisiensi }\end{array}$ & 2780 Kilogram CO2 & jpmorganclimatecare.com \\
\hline
\end{tabular}


Jurnal Riset Agama, Volume 1, Nomor 3 (Desember 2021): 112-131

Eka Mulyo Yunus, Andika, Ahmad Yani, Muria Khusnun Nisa, Hasyim

Muhammad/Revitalisasi Tafsir Ekologi pada Kandungan Surat Al-A'raf [7] Ayat

56-58 dalam Rencana Penanaman Pohon Trembesi di Lingkungan UIN

Walisongo Semarang

10L/100km dengan

jarak 12000 mil per

tahun

Tabel di atas merupakan kalkulasi emisi yang dihasilkan dalam kehidupan sehari-hari dengan batas minimal penggunaan per harinya.

\section{Dasar Hukum Pelaksanaan Pengurangan Emisi}

Sejak penyelenggaraan konferensi COP13 di Bali, pemerintah Indonesia dan Departemen Kehutanan sangat berantusias mengembangkan perangkat hukum atau peraturan yang terkait langsung dengan penurunan emisi karbon (Cifor, 2009).

Terdapat tiga Peraturan Menteri yang telah resmi diundangundangkan, yaitu: 1) Peraturan Menteri Kehutanan No. P. 68/MenhutII/2008 tentang Penyelenggaraan Demonstration Activities Pengurangan Emisi Karbon dari Deforestasi dan Degradasi Hutan; 2) Peraturan Menteri Kehutanan No. P. 30/Menhut-II/2009 tentang Tata Cara Pengurangan Emisi dari Deforestasi dan Degradasi Hutan; dan 3) Peraturan Menteri Kehutanan No. P. 36/Menhut -II/ 2009 tentang Tata Cara Perizinan Usaha Pemanfaatan Penyerapan dan Penyimpanan Karbon pada Hutan Produksi dan Hutan Lindung.

Kajian al-Quran sendiri sebagai landasan umat Islam juga memberikan arahan yang senada, tercantum dalam surat Al-A'raf ayat 56, yang berbunyi:

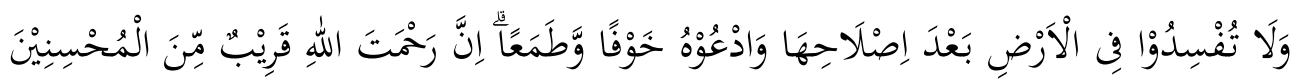

Artinya: "Dan janganlah kamu membuat kerusakan di muka bumi, sesudah (Allah) memperbaikinya dan berdo'alah kepada-Nya dengan rasa takut (tidak akan diterima) dan harapan (akan dikabulkan). Sesungguhnya rahmat Allah amat dekat kepada orangorang yang berbuat baik (Q.S Al-A'raf (7) : 56).

Dijelaskan dalam Tafsir Al-Misbah karya Muhammad Quraish Shihab bahwa melakukan kerusakan adalah salah satu bentuk perbuatan yang melampaui batas. Allah Swt menciptakan alam semesta dalam keadaan yang sempuna demi memfasilitasi segala kebutuhan makhluk dan mewajibkan untuk menjaga serta memperbaikinya. Allah Swt mengutus para Nabi dan Rasul-Nya untuk memberikan pengajaran di dalam kehidupan yang kacau, sehingga merusak sesuatu yang diperbaiki lebih buruk daripada sebelum diperbaiki. 
Jurnal Riset Agama, Volume 1, Nomor 3 (Desember 2021): 112-131

Eka Mulyo Yunus, Andika, Ahmad Yani, Muria Khusnun Nisa, Hasyim

Muhammad/Revitalisasi Tafsir Ekologi pada Kandungan Surat Al-A'raf [7] Ayat 56-58 dalam Rencana Penanaman Pohon Trembesi di Lingkungan UIN

Walisongo Semarang

\section{Rencana Penanaman Pohon Trembesi Di UIN Walisongo Semarang}

Setelah mengulas lengkap tentang pemanfaatan pohon Trembesi untuk keberlangsungan iklim di Indonesia, sudah sepatutnya civitas akademesi seperti universitas, madrasah, pesantren maupun sekolah mengambil langkah lebih awal seraya untuk membantu program pemerintah Indonesia dalam mengurangi zat emisi di negeri ini.

UIN Walisongo Semarang sendiri merupakan sebuah perguruan tinggi Islam negeri yang berlokasi di Semarang, Jawa Tengah, yang saat ini memiliki tiga letak kampus utama. Kampus pertama, berada di Jalan Walisongo No. 3-5 Semarang, kampus kedua, terletak di Jalan Prof. Hamka, Ngaliyan, kota Semarang, serta kampus ketiga, berada di Jalan Prof. Hamka, Ngaliyan, kota Semarang. Kampus yang berdiri sejak 6 April 1970 merupakan revolusi dari IAIN Walisongo pada tahun 2015 yang diresmikan kala itu oleh Menteri Agama Lukman Hakim Syaifuddin.

Kondisi letak kampus yang menaik ke atas dan memiliki jalur kendaraan di luar kampus yang padat, tentu akan menghasilkan emisi yang banyak. Ditambah dengan suhu kota Semarang yang terbilang cukup panas dengan perkiraan $32^{\prime} \mathrm{C}-36^{\prime} \mathrm{C}$ memperkirakan betapa banyak emisi yang dihasilkan di lingkungan sekitar.

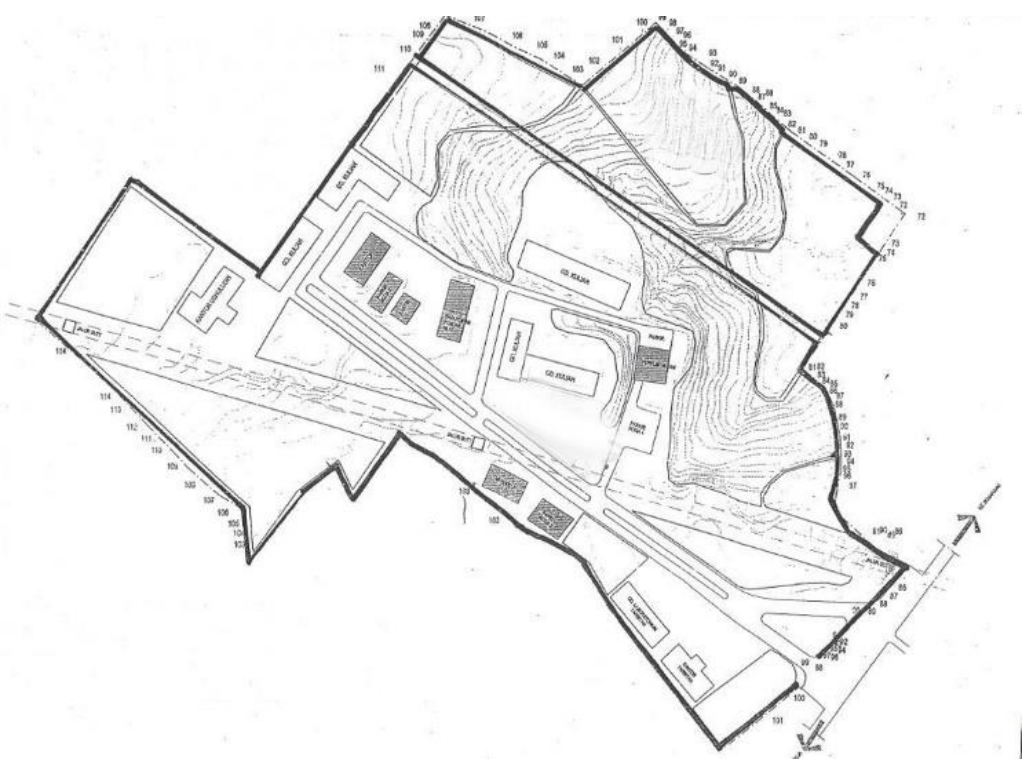


Jurnal Riset Agama, Volume 1, Nomor 3 (Desember 2021): 112-131

Eka Mulyo Yunus, Andika, Ahmad Yani, Muria Khusnun Nisa, Hasyim

Muhammad/Revitalisasi Tafsir Ekologi pada Kandungan Surat Al-A'raf [7] Ayat 56-58 dalam Rencana Penanaman Pohon Trembesi di Lingkungan UIN Walisongo Semarang

Jika kita lihat bersama, letak kampus yang luas dengan memiliki beberapa lahan kosong yang menghubungkan antara kampus 2-3 adalah sarana yang cocok untuk penanaman pohon Trembesi di lingkungan UIN Walisongo Semarang. Ditambah lagi dengan program Green Campus yang dimiliki UIN Walisongo semarang akan menambah daya guna penanaman pohon Trembesi di UIN Walisongo Semarang.

\section{Gambar 4. Green Sitting Group UIN Walisongo Semarang}
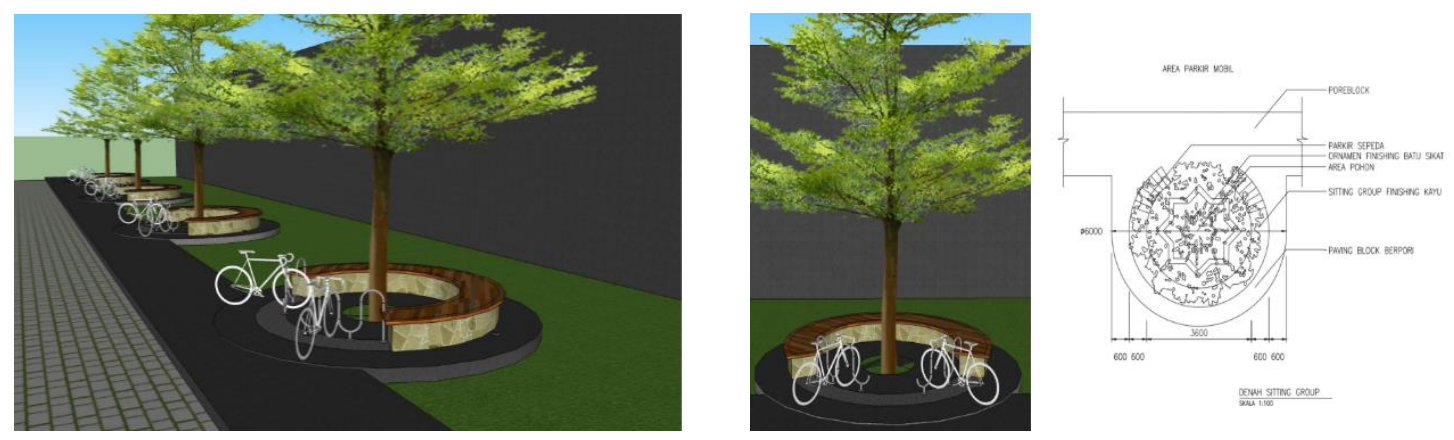

Green Sitting Group merupakan program Green Transportasion yang digalakan We Green UIN Walisongo Semarang bersama jajaran kepemerintahannya. Jika peneliti amati penggunaan lahan pohon diskusi menggunakan pohon Trembesi, maka akan menghasilkan suatu langkah preventif dalam mengurangi zat emisi di lingkungan UIN Walisongo Semarang.

Jika satu pohon trembesi dapat menyerap 28,5 ton gas CO2 pertahunnya (diameter tajuk $15 \mathrm{~m}$ ). Jika ada setidaknya 50 pohon terdapat di dalam lingkungan UIN Walisongo Semarang, maka perhitungan emisi yang dapat dikurangi, sebagai berikut:

Jumlah pohon Trembesi $x$ penyerapan karbon per pohon

$=50 \times 28.488 .39 \mathrm{Kg} \mathrm{CO} 2=14.244 .169,5 \mathrm{Kg} \mathrm{CO} 2$ per tahun

Berarti ada 14 juta $\mathrm{kg}$ emisi yang dapat dihilangkan dengan penanaman 50 pohon Trembesi di UIN Walisongo Semarang. Dan ini merupakan langkah yang sangat bermanfaat mengingat emisi di Indonesia diperhitungkan akan tumbuh 1,9\% per tahun dan mencapai 2,5 Gt CO2e pada tahun 2020 dan 3,3 Gt CO2e pada tahun 2030. Emisi pada sektor pembangkitan tenaga listrik bertambah lebih cepat dari sektorsektor lain sebesar $8 \%$ per tahun dan mencapai 810 MtCO2e pada tahun 2030. Hal ini semakin parah oleh bertambahnya kebutuhan energi yang sangat cepat dan ketergantungan pada pusat pembangkit tenaga listrik 
Jurnal Riset Agama, Volume 1, Nomor 3 (Desember 2021): 112-131

Eka Mulyo Yunus, Andika, Ahmad Yani, Muria Khusnun Nisa, Hasyim

Muhammad/Revitalisasi Tafsir Ekologi pada Kandungan Surat Al-A'raf [7] Ayat

56-58 dalam Rencana Penanaman Pohon Trembesi di Lingkungan UIN

Walisongo Semarang

tenaga batu bara. Sehingga menurut hemat peneliti penanaman pohon Trembesi di UIN Walisongo Semarang sangat layak untuk dilakukan.

\section{Kesimpulan}

Tafsir ekologi dalam surat Al-A'raf ayat 56-58 sangat berkaitan tentang tata cara menjaga lingkungan. Pohon trembesi yang menjadi objek kajian peneliti dalam ayat tersebut memiliki hubungan timbal balik yang sangat terkait baik secara hukum Indonesia dan hukum Agama. Pohon Trembesi yang jika dihitung oleh ahli dapat menyerap 28,5 ton gas CO2 setiap tahunnya (diameter tajuk $15 \mathrm{~m}$ ). Sehingga menjadi inovasi yang akan dikembangkan di UIN Walisongo Semarang. Penulis sangat berharap penelitian ini dapat memberikan manfaat bagi khazanah pengetahuan Islam dan Sains yang harus selaras dan bekerjasama. Sehingga penanaman pohon Trembesi dapat dilaksanakan dengan sebaikbaiknya tidak hanya di lingkungan UIN Walisongo Semarang namun di setiap daerah Indonesia. Penelitian ini juga memiliki keterbatasan, dikarenakan masih banyak kalangan ahli tafsir dan biologi yang melakukan penelitian ini di lingkup Universitas. Penelitian ini direkomendasikan kepada ahli tafsir, biologi serta mahasiswa dan juga instansi pemerintahan sehingga pemanfaatan pohon Trembesi dapat terus dikembangkan.

\section{Daftar Pustaka}

Abdillah, M. (2001). Agama Ramah Lingkungan: Perspektif Al-Qur'an. Jakarta: Permadina.

Abidin, A. Z. (2020). Tafsir Ekologis Dan Problematika Lingkungan (Studi Komparatif Penafsiran Mujiyono Abdillah dan Mudhofir Abdullah Terhadap Ayat-Ayat Tentang Lingkungan). Qof, 1-18. Qof: Jurnal Studi Al-Qur'an Dan Tafsir, 4(1), 1-18.

Cifor, A. (2009). Smooth 3-D Reconstruction for 2-D Histological Smooth 3-D Reconstruction for 2-D Histological. IPMI 2009: Information Processing in Medical Imaging, 350-361.

Dahlan, E. (2010). Trembesi Dahulunya Asing Namun Sekarang Tidak Lagi. Bogor: IPB press. Bogor: IPB Press.

Darmalaksana, W. (2020). Metode Penelitian Kualitatif Studi Pustaka dan Studi Lapangan. Pre-Print Digital Library UIN Sunan Gunung Djati Bandung, 1-6.

Denzin, N. K. (2009). The elephant in the living room: Or extending the conversation about the politics of evidence. Qualitative Research, 139160. 
Jurnal Riset Agama, Volume 1, Nomor 3 (Desember 2021): 112-131

Eka Mulyo Yunus, Andika, Ahmad Yani, Muria Khusnun Nisa, Hasyim

Muhammad/Revitalisasi Tafsir Ekologi pada Kandungan Surat Al-A'raf [7] Ayat

56-58 dalam Rencana Penanaman Pohon Trembesi di Lingkungan UIN

Walisongo Semarang

Hamdani, I. (2007). Filsafat Pendidikan Islam. Bandung: CV Pustaka Setia.

Hsieh, H. F. (2005). Three Approaches to Qualitative Content Analysis. Qualitative Health Research, 1277-1288.

Junaidi, A. (2014). Dekonstruksi Tafsir Antroposentrisme: Telaah AyatAyat Berwawasan Lingkungan. Kalam: Jurnal Studi Agama Dan Pemikiran Islam, 8(1), 65.

Mustakim. (2017). Pendidikan Lingkungan Hidup Dan Implementasinya Dalam Pendidikan Islam (Analisis Surat Al-A'raf Ayat 56-58 Tafsir Al Misbah Karya M. Quraish Shihab). JIE: Journal of Islamic Education, 2(1), 1-27.

Putra Haska, H., Dwi Lestari, P., \& Fitria, R. (2011). Pohon Trembesi Sebagai Alternatif Terbaik Untuk Mensukseskan Target Penurunan Emisi Karbon di Indonesia. Repository IPB, 1-9.

Saddad, A. (2017). Paradigma Tafsir Ekologi. Kontemplasi : Jurnal Ilmu-Ilmu Ushuluddin, 5(1), 50-76.

Sakti Garwan, M. (2019). Tela'ah Tafsir Ekologi Al-Qur'an Surat AlBaqarah Ayat 30: Mengungkap Sikap Antroposentris Manusia pada Kawasan Ake Jira Halmahera. Tajdid, 18(1), 23-56.

Samsoedin, I., \& Wibowo, A. (2012). Analisis Potensi dan Kontribusi Pohon di Perkotaan Dalam Menyerap Gas Rumah Kaca. Studi Kasus: Taman Kota Monumen Nasional, Jakarta. Studi E-Journal: Jurnal Penelitian Sosial Dan Ekonomi Kehutanan, 9(1), 1-27.

Sukarni. (2011). Fikih Lingkungan Hidup Perspektif Ulama' Kalimantan Selatan. Jakarta: Kementrian Agama RI.

Susandi, A. (2009). Integration of Adaptive Planning Across Economic Sector. NPW Technical Workshop on Integration of Approaches to Adaptation Planning, 12-14. 